\title{
Debt Relief for the Poorest: An Assessment of the Heavily-Indebted Poor Countries (HIPC) Initiative
}

\author{
SHALENDRA D. SHARMA*
}

High level of external debr pases a serious constraint on the ability of poor countries to pusue sustainable development and rechuce poverty. The Heavily Indebted Poor Countries (HIPC) Initiative was designed to relieve the high external debt of some of the world's poorest nations by either writing-off or reducing debt to sustainable levels. It was launched by the World Bank and the International Monetary Fund (MF) in 1996 and "enhanced" in 1999 to expand and accelemate the process of debt relief and free scarce public resources for sustainable economic development, in particular, broad based development to reduce poverty. Whether debt relief, in general, or the HIPC Initiative, in particular, can achieve such development outcomes has been the subject of much debate. 'I his paper argucs while the HIPC initiative is a positive step towark debt relief and sustainability, it is important to note that sustainable debt is not an end in itself, but should be an essential element in realizing the growth needed to reduce poverty and achieve the Millennium Development Goals (MDGs). To realize the full potential of debt relief, donor countries will not only have to be more generous, and the recipient countries need to undertake decper structural reforms, debt sustainability assessments should specifically take into account how the poor countries can achieve the MDGs.

Keywords: HIPC, debt-relief, Millennium Development Goals, low-income countries, third-world debt

\footnotetext{
I wish to thank my colleagues in the Department of Economics at the University of San Francisco, and at the World Bank for their comments on earlier dratts. Comments from two anonymous reviewers of this journal greatly improved this paper. All remaining errors are mine.

Direct all correspondence to Shalendra D. Sharma, Professor, Department of Politics, University of San Francisco, 2130 Fuleon Street, San Francisco, CA 94117-1080, USA; 'Tel: 1-415-422-6452; b-mail: sharmas (a)usfracciu
} 


\section{INTRODIJTION}

I

n the final wecks of 1999 , tens of thousands of people in more than 60 countrics would regularly and symbolically form human chains to pray, sign petitions and peacefully protest for an end to global inequality, injustice and poverty. This campaign mounted by Jubilee 2000 , a world-wide citizens movement founded in 1995 and led by the charismatic pop-star Bono, made the cancellation of all debt held by the world's poorest countrics the centerpicec of their demands. ${ }^{1}$ In their passionate appeals, the campaign organizers argued that debt was not only an unjust burden on the world's poor who were paying for obligations incurred by unaccountable and corrupt regimes and imprudent foreign lenders, but that debt cancellarion would free resources that could be used to promote sustainable economic development and assist in the eradication of mass poverty in the developing world. They demanded immediate action by explicitly urging citizens of the creditor nations to put pressure on their governments and indirectly the international financial instinutions, namely the World Bank and the IMF, to work towards a complete cancellation of the debt held world's poor countries by the end of 2000 .

By the end of the campaign and on the eve of the new millennum over 25 million people from around the world had signed the Jubilee 2000 petition - making it the first-cver global pertition and one with the biggest. number of signanures ever collected on one single issue. The signatures not only included thumbprints from the poor and the illiterate, but also those of the famous and powerful, including Pope John-Paul II, the Dalai Iama, President Bill Clinton, several members of the I'S Congress and Senate, heads-of-state from some 147 countries, Linited Nations secretary-general Kofi Annan, Bishop Desmond 'Iutu, Muhammad Ali, several Noble laureates, and Hollywood stars, among others.

Keeping the promise he made to Bono, Kofi Annan made debt cancellation one of the key issucs at the Millennium Summit sponsored by the United Nations in Seprember 2000. At the Sunmit, cach member country of the UN made a comnitment to work toward a world in which sustaining economic development and climinating poverty would have the highest priority. The 189 member nations of the UN General Assembly (including the heads-of-state of 147 countries present at the Summit) unanimously issued a joint statement pledging to work toward meeting a set of seven specific developmental targets in poor countries by the year 2015. These targets dubbed the "Millennium Development Goals" (MDG) are all-encompassing and ambitious (UNDP 2003). The goals include:

- One: reduce the proportion of people living in extreme poverty (or the proportion of people whuse income is less than $\$ 1$ a day) by half between 1990 and 2015.

- Two: Achieve universal primary education for all children everywhere by 2015.

- Three: Promute gender equadity and ennpower women by eliminating gender disparity in primary and secondary education preferably by 2005 and in all levels of education 
no later than 2015.

- Four: Reduce infant and child mortality rares by two-thirds, berween 1990 and 2015.

- Fine: Improve matemal health and reduce the maternal mortality tatio by three-quarters berween 1990 and 2015.

- Six: Combat HIV/AIDS, malaria, and other diseases and halt and reverse the incidence and spread of these discases by 2015.

- Seven: Implement national strategies for sustainable developnent by 2005 by integrating the principles of sustainable development into country policies and program so as to reverse the loss of environmental resources by 2015.

In December 2000, Annan was authorized by the UN General-Assembly to prepare a "road map" of how to achieve the goals laid out in the Millennium Declaracion. After extensive deliberations, Annan's office issurd its road-map in September 2001. Drawing on the agreed-to seven goals it proposed an eighth goal. T'ermed "a global partnership for development,". the eighth goal comprehensively outlined the "mutual responsibilities and obligations" of the UN mernber states. For example, developing countries were required to promote good governance, strengthen the rule of law, reduce corruption and provide incentives for economic growth. On the other hand, the developed or the "rich" nations were obligated to provide more gencrous ODA (official development assistance), especially to the pxorest or the least developed countries (L.DCs), nondiscriminatory access to their markets for poor countries exports, including tariff and quota free access for least developing countries exports, and meaningful debt-relief - specifically, "enhanced program of debt-relief for the HIPCs (heavily indebted poor countries), cancellation of official bilateral debe" and commitment co deal comprehensively with the debt probkems of developing countries through national and international measures in order to make debt sustainable in the long term and ultimately end sovereign defaults. ' In December 2001, the LiN General Assembly formally adopted resolution 5695 approving the eighth goal (UNDP 2003).

\section{THE HIPC INITIATIVE}

In the academic literature the main rationale for debt reduction have rested on the concept of "debt overhang" - or when the cost of a country's unserviceable foreign debt, taken with a decline in the economy creates disincentives for an over-indebted country to invest and adjust. According to Krugman 1988 and Sachs 1986, debt must be reduced to sustainable levels before economic development can take place. ${ }^{3}$ Ihis literature inspired several debt-reduction schemes mainly for highly indebted medium-income countries for which an active secondary market in their bank-held debt existed, and rangitg from small buybacks of debe to the Brady deals. ${ }^{1}$

In contrast to middle-income countries, the debt crisis in low-income countries 
emerged rather slowly as payment difficultics (the first real manifestation of problems) were initially addressed through new net lending and debt reschedulings - first on commercial and subsequently on increasingly concessional terms. However, gradually it dawned on the various stakeholders that the debt stocks of many of these low-income countries were effectively unsustainable and that indebtedness was acting as a major constraint to growth. By mid-1995, the World Bank acknowledged that the external debt situation for a number of low-income LDCs had become extremely difficult, undermining the prospects for economic development. For these countrics, even full use of traditional mechanisms of rescheduling and debt reduction (such as the Naples terms and debt swaps), combined with continued provision of concessional financing was not proving sufficient to attain sustainable external debt levels. ${ }^{5}$ In Scptember 1996, the Interim and Developmene Committees of the IMF and the World Bank launched a program jointly proposed by the two institutions to address this situation. Endorsed by 180 governments, the "Heavily Indebted Poor Country" (or the HIPC) Initiative is an agreement among official creditors designed to help the poorest, most heavily indebted countries escape from unsustainable debt and to focus their energies on building the policy and institutional foundation for sustainable development and poverty reduction. Specifically, the HIPC is designed to provide assistance to cligible countries - that pursue economic reforms and where traditional debt relief mechanisms arc not enough to help them exit from the rescheduling process - by helping them reduce their external debt burden to sustainable levels via reduction in the net present value (NPV) of the future claims on the indebted country. It was believed that this would enable them to service their debt through export earnings, aid, and capital inflows.

It is no exaggeration to say that the HIPC marked a radical departure from previous approaches to debt relief for the poorest countries. It was the first time in their 50-year history the debts of the World Bank and the IMF ("preferred creditors" to whom debts have always to be repaid first) was included for write-off under the scheme. In fact, the HIPC was also the first attempt by creditors to deal with the debts of the poorest countries in a comprehensive way. Previously debtor nations negotiated scparately, and at great cost, with sets of bilateral (government to government) or multilateral (institutions owned by a range of governments) or private creditors. As a result their debts were not viewed as a whole. HIPC changed that because it required the participation of all multilateral creditors, beyond the tratitional debt relief mechanisms provided by official bilareral and private creditors. ${ }^{7}$ Moreover, all creditors were to participate in providing assistance beyond current mechanisms as required to reach debt sustainability. Creditors also had to share the costs of HIPC assistance on the basis of broad and equitable burden sharing and provide relief on a basis that is proportional to their share of the debt after the full application of traditional forms of debt relief - including the Naples terms from Paris Club credirors which provide a 67 percent NPV reduction on eligible debr. ${ }^{8}$

While the Initrative did provide encouraging carly results (in particular, a much-nceded 
respite from high debt service), it was also felt that the HIPC initiative was not living to its goal of delivening its stated goal of providing a 'lasting exit' to unsustainable debt burdens for the world's poorest countries. A major review in 1999 resulted in a significant enhancement of the original framework. It was hoped that the "Enhanced HIPC Initiative" would make debt relief "deeper, broader, and faster," and provide increased protection against external shocks and greater levels of debt cancellation. Furthermore, the enhanced inutiative explicitly linked debt relief to puverty reduction with the view that the elimination debt would allow countries to invest more in their future. The cnhanced HIPC Initiative signaled not just a bigger debt reduction program but a new way of providing support to developing countrics. Since then, several bilateral creditors including all the $G 7$ countries have announced that they would provide 100 percent debt cancellation for all HIPC countries.

\section{ELIGIBILITY}

The World Bank and IMF cxplicitly state that in order for a country to be eligible for debt relief under the HIPC initiative they must: (a) be eliggible only for concessional assistance from the IMF and the Wotld Bank, (b) face an "unsustainable debt burden, beyond available debt relief mecharisms." Specifically, 'available debt relief mexhanisms' means the deht relief that is provided by the Paris Club group of creditors. Paris Club creditors will usually provide a reduction of up to two thirds of the net present value of eligible debt - in orher words, debt which was contracted before a certain "cut-off date." Aid debt is usually excluded from this, and is only rescheduled at a lower rate of interest. Other bilateral and commercial creditors are also assumed to provide similar reductions, although in practice they may not do so, (c), eligible countrics need to demonstrate the capacity to prudently use the assistance granted by establishing a satisfactory track record under IMF and International Development Association supported programs and establish a track record of reform and sound policies through IMF and World Bank supported programs for three years. That is, before qualifying for the HIPC initiative (or before they are accepted for debt relief), countries must demonstrate a good track record of economic management measures such as economic stabilization programs, public sector reforms, and reorientation of public spending toward poverty reduction, health, education, and pro-poor gtowth, and (d), since a key input in this process is the poverty reduction strategy paper, eligibility requires that it be prepared with broad participation of civil socicty, and serve as the basis for implementing the country's poverty reduction strategy. Funds freed up by this debt relief are to be used for poverty reduction programs rather than repayments. Altogether, 42 countries initially decmed to be eligitble for HIPC assistance. These include: Angola, Benin, Bolivia, Burkina Faso, Burundi, Camoroon, Central African Republic, Chad, Republic of Congo, Democratic Republic of Congo, Cote d'Ivoise, Ethiopia, The Gambia, Ghana, Guinca, Guinea-Bissau, Guyana, 
Honduras, Kenya, Lao PDR, Liberia, Madagascar, Malawi, Mali, Mauritania, Mozambique, Myanmar, Nicaragua, Niger, Rwanda, Sierra Leone, Sao Tome Principe, Senegal, Somalia, Sudan, Tanzania, Togo, Uganda, Vietnam, Yemen, Zambia. However, four of these (Kenya, Yemen, Angola and Vietnam) are considered to already have a sustainable level of debt, and are thus unlikely to receive further debt cancellation.

The HIPC initiative works in two stages. First, countries reach "Decision Point" when theit debt is deemed unsustainable even after the full use of 'traditional' debt relief mechanisms, and that they have adopted adjustment and reform programs supported by the IMF and the World Bank and established a sarisfactory track record. ${ }^{10}$ To facilitate this, the debtor country, the World Bank and the IMF Staff prepare a Debt Sustainability Analysis (DSA) to determine to wherher a country is facing an unsustainable debt situation after the full application of traditional debt relicef mechanisms, and how much relief needs to be provided by multilateral, bilateral and commercial creditors. For most countries, a country's debt is deemed to be unsustainable if the net present value of its total external debt is more than 150 percent of its average exports." For councries which are "exceptionally open" (with an export-to-GDP ratio of more than 30 percent), exclusive reliance on external indicators may not adequately reflect the fiscal burden of extcrnal debt. '1hus, for these countries which have a very high debt in relation to fiscal revenues despite a relatively good revenue performance a debt-to-revenue criteria (an export-to-GDP ratio of at least 30 percent and a minimum threshold of fiscal revenue in relation to GDP of 15 percent) is applied. Also, for these countries, the NPV debt-to-export target will be set at a level which achieves a 250 percent of the NPV debt-to-revenuc ratio at the decision point.

Second, to ensure that debt relief translated into real poverty reduction, it was agreed that debt relief must be part of a comprehensive poverty reduction strategy comprised of a range of polices aimed at improved social programs, good governance and shared economic growth. Under the enthanced framework, debt relief is to be linked to the establishment of national poverty reduction strategies developed by governments to ensure that debt relief made a real difference in the lives of the poor. Countries are required to prepare a "Poverty Reduction Strategy Paper" (PRSP) through a broad based participatory process that included civil society, key donors and regional development banks. ${ }^{12}$ The World Bank and the IMF, in coordination with the larger development community, were to provide assistance to countries in developing PRSPs. However, the decision as to whether or not countries have reached Decision Point is made entirely by the World Bank and IMF, with no participation of the debtor government in cithor debtor or creditor nations. Once a country reaches its decision point, it may immediately begin receiving interim relief on its debe service falling due. Thus, at the Decision Point, creditors commit to providing sufficient amounts of debt relief to ensure that the countries debt is reduced to levels deemed sustainable. However, the debt is not actually catacelled until "Completion Point." 13 That is, once countries have passed Decision Point, they are required to establish a further 
track record of good performance under IMF/World Bank supported programs beforc they reach Completion Point. The length of this second period depends on (a) the satisfactory implementation of key policy reforms agreed at the decision point, (b) the maintenance of macroeconomic stability, and (c) the adoption and implementation for at least one year of the PRSP. Once a country has met these criteria, it can reach its completion point, at which time lenders are expected to provide the full relief committed at the decision point. For countries that reached Decision Point with only an interim Poverty Reduction Strategy Paper (PRSP), there is also a recuirement to prepare a full PSRP and to implement their poverty teduction strategy for at least one year.

At Completion Point, the full deht cancellation which was committed at Decision Point is provided. In fact, debt relief becomes full and irrevocable at the end of the completion point. ${ }^{14}$ In November 2001, the IMF/World Bank agreed that further relief may be provided at Completion Point where external conditions have worsened significantly between Decision and Completion Points. Indeed, this is an innovative feature introduced in the enhanced initiative illustrates that the initiative has some flexibility to review a country's debt conditions at the completion point and assess whether additional debt relief is required to cope with the unexpected increases in the debt burden. This feature prevents HIPCs from being penalized for events outside their control. As of March 2003, only Burkina Faso, which has a relativily small external debt, had bencfited from so-called "topping up" of relief. 's By April 2004 , twenty-seven HПPCs or more than two-thirds of the thirty-cight countries that potentially qualify for assistance under the iniriative have reached the decision point. Fourteen HIPCs have reached the completion point, most recently, Ghana in July 2004joining Benin, Bolivia, Burkina Faso, Ethiopia, Guyana, Mali, Mauritania, Mozambique, Nicaragua, Niger, Senegal, Tanzania, and Uganda. Of the 17 countries in the interim period, 11 are on track with their macroeconomic programs. Three countries (Democratic Republic of Congo, Gunea-Bissau and Sierra Leone) have yet to complete their PRSPs. Finally, progress in reaching the decision point for the remairing 11 HIPCs (Burundi, Central African Republic, Comoros, Republic of Congo, Cote d'Ivoire, Iao P.D.R, Liberia, Myanmar, Somalia, Sudan and Togo), that have yet to do so is urgent since the sunset clause of the HIPC. initiative is due to take effect at end-200/ (IMF-IDA, 2004).

\section{ACTUAL DEBT CANCELLATION UNDER HIPC}

The HIPC Initiative is the first comprehensive effort to eliminate unsustainable debt in the world's poorest, most heavily indebted countries. It introduced a new approach to debt relief by focusing on overall debt sustainability. Debt relief is based on a country's ability to pay within a total context of poverty reduction and economic growth. It thereby provides an opportunity for countries to exit from the debt rescheduling 
process. It also represents a commitment by the international community, including all creditors, to act together in a coordinated and concerted fashion to reduce debt to a sustainable level. But, what has the HIPC actually delivered?

In June 1999, the G7 leaders pledged in Cologne that a total of $\$ 100$ billion of HIPC debt would be cancelled. In December of that year, a further $\$ 10$ billion was committed through 100 percent cancellation from bilateral creditors. However, half of this (\$55illion) was debe cancellation that had already been committed through traditional debt cancellation through the Paris Club, or under the original HIPC initiative. In September 2002 , creditors committed a further $\$ 1$ billion of debt cancellation under HIPC in order to provide topping up for countries affected by worsening commodity prices and thus lower than expected exports when they reach Completion Point.

Assessing the amount of debt which has acrually been cancelled is made difficult by the fact that under the HIPC initiative, debt cancellation is committed at Decision Point but only delivered at Completion Point. When announcing the amount of relief that has been delivered, the World Bank and IMF usually include all the relief cornmitted to the countries past Decision Point. This is because countries gain relief on their debt service as from Decision Point, meaning that the total stock of debt has little relevance if it does not have to be serviced. However, this can overstate the amount of cancellation that has taken place, particularly given that most countries arc facing delays in reaching Complction Point, and that almost one third of the countrics between Decision and Completion Points have had some of their interim debr relief suspended.

All this has to be viewed in the overall context of the serious debt problem facing developing countries. All developing (both low and middle-income) country debt rose from $\$ 500$ billion in 1980 to $\$ 1$ trillion in 1985 and around $\$ 2$ trillion in 2000 . In 2002 , the external debt of low-income councries stood at about $\$ 523$ billion. Of this $\$ 399$ billion was public and publicly guaranteed debt. Low-income countries owed $\$ 10$ billion to the World Bank Of this, $\$ 82$ billion was owed to the International Developaxent Association ( $\Pi \Lambda$ ) the part of the World Bank that provides zcto interest luans and outright gtants to the poorest nations. ${ }^{16}$ The 41 HIPC countrics saw their total indebtedness increase from $\$ 60$ billion in 1980 to $\$ 105$ billion in 1985 and $\$ 190$ billion in 1990 - and would have been in the absence of debt reduction near $\$ 200$ billion in 2000. Seen from another angle, the HIPCs nominal debt stocks rose from moderate levels in the early 1980 s to some 800 percent of exports and 160 percent of gross national incume in the mid-1990s (IMF 2003, 6). The 27 countries that already qualified under the HIPC Initiative owe about $\$ 110$ billion and will receive about $\$ 53$ billion in debt relief over the next 20 years. This translates to their debt being cut, on average, by two thirds in NPV terms. ${ }^{17}$ Debt service obligations (as a percentage of exports) of the countries obtaining dett relief declined from an average of 15.7 percent in 1998-1999 to 9.9 percent in 2002 and annual debt servicc is projected to be about 30 percent lower during 2001-2005 than in 
1998-1999 - freeing about \$1 billion in annual debt-scrvice savings (IMF-1DA 2004, 11). As Table 1 shows, indicators of debe sustainability such as debt-to-exports tatios and debt-service ratios are forecast to be cut by 50 percent or more after debt relief to levels comparable to, or below, those of other low-income countries.

Table 1: Deb'l Indicators for hipCs that have Reached Decision Point

\begin{tabular}{ccc}
\hline & $\begin{array}{c}\text { Before cnlanced } \\
\text { HIPC relief }\end{array}$ & $\begin{array}{c}\text { HIPC relief at } \\
\text { completion point }\end{array}$ \\
\hline NPV of debt-to-exports ratio & 274 & 128 \\
NPV of dctot-tu-CiDP ratio & 61 & 30 \\
Debt service-to-exports ratio & 16 & 8 \\
\hline
\end{tabular}

NOTE: a. Before enbanced HIPC relief: debt stocks after traditional Paris Club relief, but before the HIPC decision point. Data refers mostly to end-1998 and 1999 (for debt service, average of 1948-1959).

b. HIPC relief at completion point: Cosccast for 2005.

c. NPV of debt-in-expons ratio: exports are defined as the three-year average exports of goods and services up to the date specified.

d. Debt service-tcexponts rasio: exports are defined as goods and services in the current year. SOURCl: Worid Bank (2004b, 119).

Evidence from graduating HIPC does show that they have benefited from more favorable debt-scrvice profiles (as a result of the longer grace periods for payment), and lower interest rates on restructured debts. Equally important, the initiative's emphasis on expenditures in the social services has served to appreciably increase spending in these sectors in national budgets (Gautam 2003). The savings from the HIPC. initiative are being directed into areas such as health and education and anti-poverty programs. The case of Ghana is illustrative: On $13 \mathrm{July} 2004$, the IMF and the World Bank's International Development Association (IDA) agreed that Ghana has taken the necessary steps to reach its completion point under the enhanced HIPC Initiative. Total debt relicf under the enhanced HIPC Initiative from all of Ghana's creditors amounts to US\$3.5 billion in nominal terms. This assistance is equivalent to a reduction in NPV terms of US\$2.2 billion, as agreed at the decision point. Ghana qualified under the fiscal criterion and the debt relief was calculated to bring the NPV of debt-to-government tevenue ratio down to the HIPC threshold of 250 percent. IDA will provide debt relief under the enhanced HIPC. Initiative amounting to US\$1.4 billion in debt service relief (US\$782 million in NPV terms), to be delivered through a 67 percent reduction in debt service on IDA credits from 2002 to 2022. The IMF will provide debt relief of US $\$ 112$ million in NPV terms on payments falling due to the IMF during 2002 to 2009. The remaining bilateral and multilateral creditors are also expected to provide their share of relisf required under the enhanced HIPC Initiarive. In addition, many bilateral creditors have indicated their intention to provide additional relief beyond the enhanced HIPC Initiative (estimated to total about US\$500 million in NPV terms). Between 2004 and 2013, Ghana would save 
approximately US $\$ 230$ million annually in debe service costs. Debt relief, wogether with bilateral assistance beyond HIPC relief, will lower Ghana's debt-to-expott rario to 84 percent and its debt-to-government revenue ratio to 130 percent in 2004 . Those levels are 66 percentage points and 120 percentage points, respectively, below the HIPC thresholds. Resources made available by debt relief under the enhanced HIPC Initiative are being allocated to fund pro-poor expenditure programs, as outlined in Ghana's Poverty Reduction Strategy (GPRS) Paper, which was completed in February 2003 using an extensive participatory approach. The GPRS has five strategic pillars: (i) macroeconomic stability; (ii) production and employment; (iii) human resource development; (iv) special programs for the vulnerable and excluded; and (v) governance.

Before the HIPC Initiative, eligible countries were, on avcrage, spending slightly more on debt service than on health and education combined. This is no longer the case in the 27 countries receiving HIPC relief. Under their recent IMF and World Bank-supported programs, these countries have increased their expenditures on health, education and other social services. For example, in African countries receiving debt relief under the initiative, poverty reduction spending has increased from 38.6 percent of government revenue in 1999 to 48.1 percent in 2001 . Tanzania received $\$ 3$ billion in debt telief and has used the initial debt service savings to increase education spending and eliminate school fees for elementary school education. Almost overnight, an estimated 1.6 million kids returned to school. Similarly, Mozambique increased health spending by $\$ 13.9$ miltion. Half a million children are tring varcinated against tetanus, whooping cough and diphtheria, increasing coverage to 80 per cent in the last 2 years. Also, $\$ 10$ million is being spent on clectrification on rural schools and hospitals, and rehabilitation of infrastructure following the floods. $\$ 3.2$ million is being used to increase the number of girls attending school, and scores of new primary schools are being built (IMF 2003a). These are important - albeit modest - gains as prior to the HIPC, debt service obligations, which had risen to consume latge shares (in many cases more than half) of poor countries export earnings stood as a major obstacle to development.

\section{IIMITS OF THE IIIPC AND MAKING IT WORK BETTER}

While the initiative has been generally successful in reducing most HIPCs external debt and their debt service (on average) in par with or below the levels of other poor countries, the premise that the HIPC is also providing long term external debt sustainability through a "permanent exit" from debt rescheduling, is highly problematic. That is, although the external debt stocks of HJPC completion point countries have been reduced, exiting from the HIPC initiative, by itself, does not guarantee long-term external debt sustainability. Rather, the structural weaknesses combined with fragile macroeconomic management can easily push completion point countries back into the debr trap again. Moreover, since all HIPCs are heavily dependent on primary commodities for their export carnings and government revenue, they remain vulncrable 
to declines in world commodity prices and other adverse exogenous developments. Given this, the World Bank and the IMF's Debe Sustainability Analysis should be viewed with somc caution as it does not take into account the high vulnerability of the HIPCs ro external shocks - such as the volatility of commodity prices, exchange rate devaluations, oil shocks, declining terms of trade, variable donor aid flows and non-economic shocks such as climatic disasters, conflicts, political instability and the devastating impact of HIV/Nids in sub-Saharan $\Lambda$ frica.

Indeed, the NCiO, Jubilee Research has pointed out that the DSA projections are usually based on the 'best possible case' scenarios rather than a realistic assessment of the political and economic contexts in which the HIPC countries find themselves. ${ }^{18}$ For example, the average export growth for HIPC countrics in 2000-2001 was 5.1 percent - not 9.4 percent as projected by the IMF. Real GDP growth was 4.3 percent - almost one percentage point less than the levels predicted by the IMF. Analysis of the 24 HIPC countries that had passed decision point as of January 2002 showed that IMF projections were out by more than a few percentage points. Similarly, in April 2002, the World Bank admitted that that of the six countries that had by then passed their Completion Points, at least two still did not have a sustainable level of debt. Specifically, debt ratios for Uganda and Mali deteriorated after complction point as a result of declines in commodity prices, under-delivery of debt relief by some creditors, higher-than-expected new borrowing, and a decline in discount rates (IMF-IDA 2004, 11). Thus, the dissonance between debt payments and growth and that fact that payment and borrowing decisions in HIPC are often predicared on growth projections that do not materialize do not augur well for long-term sustainability. Second, to Jubilec Rescarch the HIPC initiative's definition of debt sustainability is flawed and unattainable because it tends to focus on debt stucks rather than dobt service. They argue that debt sustainability must be explicitly linked to the resources needed to achieve the MDGs. Ihat is, "affordable debt service" would be calculated as a residual from the revenue base after taking account of the necessary spending to meet the MDGs and to service domestic debt. In addition, affordable debt service should be determined by an independent review panel with representatives appointed by both the creditor and debtor nations. ${ }^{19}$ In fact, to NGO's like CAFOD (Catholic Agency for International Development) and Jubilee Research, since dcbt cancellation under the HIPC falls far short of what is needed, it should be replaced by new infusions of aid and a complete write-off of all HIPC debt.

No doubt, achieving debt sustainability has proven to be difficult. The external debt sustainability of half of the 20 countries which were between Decision Point and Completion Point at that time had siguificantly worsened. Indeed, the Worid Bank at the time concluded that of these countries in the interim period, 8-10 could have debt-to-export ratios above 150 percent even at their Completion points - i.e., even at Complerion Point the debt levels of these countries would still be regarded as unsustainable by the World Bank and IMF's own critcria. Tinally, while country data demonstrates that HIPC countries are seeing clear gains, it has taken time 
and effort to ensure that money is redirected to aid the poor in ways that most reduce poverty. Thus difficult problems remain. For cxample, in war-ravaged Rwanda and Ethiopia, pressing reconstruction needs may mean large new loans at the same time that old debt is being reduced. Intractable problems also remain in HIPCs that have not yet been able to reach their decision points. Some of these countries are plagued by uneven policy records or poor governance, which in turn may be caused by the scrious problems that their governments confront, including civil conflict. Some HIPCs have debts too large to write off given current funding for the Initiative. This is true, for example, in Liberia and Sudan, both of which are afflicted by civil conflict.

Clearly, achicving debt-sustainability remains a major challenge for the HIPC. Because many of the low-income countries will need to continue to bortow to meet their developmental needs, coupled with their limited repayment capacity, it means that even the HIPCs that have reached their completion points will always stay below the debt sustainability thresholds. It should also be recognized that even if all of the external debts of some HIPCs were forgiver, most would still depend on significant levels of concessional external assistance. 'Ihis is because unmanageable debt is a symptom of deeper structural problems and one-time debt relicf provided by the HIPC initiative docs not guarantec that the problem will not remerge. To get out of this vicious cycle, it makes sense to provide outright grants and loans only on highly concessional terms to help these countries achieve long-term debt sustainability. Not surprisingly, many NGOs argue that not only should the debt-service targets be tailored to each country's situation, rather than set at a uniform $150 \%$ for all HIPCs, but also that the level of debt cancellation provided by the HIPC program be deeper. However, the prospects for this happening anytime soon are not very encouraging. Thus, in the absence of adequate grants, the HIPCs may need to continue to borrow to mete their developmental needs. $\Lambda$ s Gautam (2003, xiv) notes, "in fact, there was a sharp decline in global net resource transfers starting about the time the initiative was created. As a result, although the HIPC as a group are getting an increasing share of the declining global aid resources relative to other pour countries, they are not receiving additional funds in absolute terms compared with what they were receiving before the creation of the initiative (that is, until 1995)."

Also, as Gautam (2003) points out, while the initiative has served to increase health and education spending, such as emphasis also presents a major challenge as the initiative's performance criteria are more focused on expenditures than on outcomes - even when increased expenditures may encounter absorptive capacity constraints. Gautarn (2003) aptly notes that more focus on growth-enhancing programs is now warranted. Furthermore, for debt reduction to have a tangible impact on poverty, the additional resources need to be targeted at the poor. That is, HIPC debt relief can be fully beneficial to a country only if it is provided in addition to increased rates of development assistance. A comparison of current debt service payments and concessional assistance illustrates how important continued aid programs are to these 
countries. The ratio of gross inflows (from long-term debt and grants) to debt service paid averaged about two-to-one for the HIPCs as a group during the 1990s, and ranged upwards four-to-one in half of these countries. Annual net transfers to the HIPCs on medium and long-term resource flows (including grants) averaged about 10 percent of GNP over 1990-1996. Thus, debt reduction must be additional to development assistance. This means that industrial countries can grcatly help by meeting the UN target for offecial development assistance of 0.7 percent of GNP per year rather than the current levels of foreign aid at 0.24 percent of GNP. This assistance will need to be complemented by greater access to industrial country markets so that developing countries can carn their way in the global cconomy. Without such commitments, the HIPC will have great difficulty in meeting the MDGs.

A key requirement for qualification for HIPC relief is a track record of strong policy performance. The countries that have reached completion point have had relatively strong policy track records. However, the applicarion of the policy performance requirement was progressively weakened in the enhanced HIPC - particularly, for countries that qualified in late 2000. Many of these countries have yet to demonstrate an ability to put such frameworks in place, raising concerns about the achievement of the HIPC objectives for thesc countries. This problem is compounded by the fact that several potentially eligible HIPCs face major challenges in reaching their decision points. Most of thesc councries are affected by conflict and several suffer from protracted arrears. ${ }^{20}$ The challenges are daunting as these countries strive to achieve peace and internal stability, pursue effective economic policies, and develop their cconomic management capacity. Satisfactorily completing the PRSP process has proven to be difficult for these countries as many have large displaced populations and are facing difficulties in undertaking the broad-based participatory process that the PRSP requires.

It is critical that the donor community provide these countries with the appropriate assistance by the end of 2004 when the sunset clause of the initiative takes effect. 'To this end, donors must cnsure the full delivery of debe relief under the HIPC Initiative by all creditors, particularly the remaining multilateral, official bilateral and commercial creditors. Creditors that have not yet participated in the HIPC. Initiative to contribute their share to reducing HIPCs debt must be encouraged to do so as soon as possible. Indeed, the donors' decision to extend the existing sunset clause under the enhanced HIPC Initiative by a further two years to end-2006 will grearly help the remaining countries that could qualify to establish a policy track record and be considered for HIPC relief. ${ }^{21}$ Similarly, efforts must be made regarding how best to approach debt sustainability and borrowing strategies for poor countries exicing from assistance under the HIPC initiative; and for thosc councries that are not HUPC-eligible, but are poor and vulncrable to shokks. Equally important, while overall creditor participation in the HIPC initiative has been strong, it is not yet unanimous. In particular, participation by commercial creditors bas been limited, and nine HIPCs are facing litigation on credits held by commercial creditors. ${ }^{22}$ Since the settlement of such claims could involve substantial costs to debtors, it is imperative that ways 
are found to assist these countries.

Finally, Christensen (2004) drawing from the experiences of sub-Saharan Africa notes, that the unsustainability of domestic debt is just as big a threat as the unsustainability of foreign debt. Although, domestic debt in most sub-Saharan African countrics is much smaller than external debt, interest rates are often higher, and the debt must be rolled over frequently (on average of four times a ycar), adding further to the cost of scrvicing. 'This means that some countrics spend as much funds servicing their domestic debt as they do servicing their external debt. In fact, almost all HIPC countries spend a significant part of their budgetary revenues servicing domestic debt. While the author correctly notes that doncstic debt is not necessarily bad if the funds are invested wisely, he found that in majority of the twenty-eight low-income countries in his sample, even modest levels domestic debt rended to crowd out investment in the private sector - thereby deterring economic development. He also notes that since poor countries have a very narrow investor base consisting of mainly commercial banks, govemments can quickly become captive to the interests of a few major banks. Unfortunately, as Christensen aptly notes, resolving the problems of domestic debt are not as easy as forgiving extcrnal dcbt as it may be unreasonable to expect domestic agents to forgive part of the debt as done with foreign debt under the HlPC initiative. Furthermore, paying down domestic debt would result in a significant liquidiry expransion with the potential to destabilize the economy. Thus, "the first best solucion would be for governments to reduce fiscal deficits and climinate the need for domestic borrowing, or even to pay down domestic debt" (Christensen 2004, 11). Also, donor support, provided through a trust fund that swaps domestic debe for claims on the fund could be a solution. The author argues that such a fund could reduce the cost of the debt because it would be backed by foreign currency assets. However, short of such donor-supported action, governments could also seek to strengthen their financial sectors which would help them diversify the debt and lengthen its maturity profile. Christensen notes that since all HIPCs have large public expenditure needs, such fiscal tightening needed to reduce donestic debt will have hugely ncgative impact on the vast majority of people. Thus, donor supported-action is critical to deal with this problem.

\section{CONCLUSION}

While many factors contribute to poverty in low-income countries, in about half of the 80 poorest countries, unsustainably high external debt has become a kcy constraint on development. No doubt, teducing poverty requires comprehensive debt-reduction. In the past several years there has been an extraordinary degree of coordination among a wide tange of stakeholders to make the debt-relicf IIPC program work. These partners include creditor and debtor nations, mulrilateral organizarions, as well as NGOs, churches, and other groups from civil socicty. However, in the end, the HIPC. 
initiative is neither designed nor intended to be a permanent mechanism, and can only support, but not guarantee long-term debt sustainability. Thus, it is critical that debtor countries concinue with the economic, social, political and institutional reforms and avoid unsustainable debt burdens. These countries must improve their public expenditure management along with intensified and sustained efforts to accelerate economic growth. They must continuc to implement national poverty reduction and growth strategics, and above all, adopt a cautious approach to new borrowing and keep indebtedness in line with their capacity to repay. For their part, the OECD countries and the donor community must provide the financing necessary to cover the cost of dcbt relief. Specifically, more official development assistance is critical. Moreover, the OECD countries must open their markets for poor countries, and assist with capacity building and provide well-targeted debt relief. Without such a comprehensive approach, the HIPC Initiative may not live up to its potential and holp these countries achieve the Millennium Development Goals.

\section{REFERENCES}

Bcsky, Timothy and Robin Burgess. 2003. Italving Global Poverty. Joumal of Economic Perspertives 17 (3) Summer: 3-22.

Bhagwati, Jagdish. 2004. In Defense of Globalization. New York: Oxford University Press.

Birdsall, Nancy and Brian Deese. 2004. Hard Currency. Washington Monthly March: $1-7$.

Birdsall, Nancy and John Williamson with Brian Deese. 2002. Delivering on Debt Relief: From IMF Gold to a New Aid Arcbitecture. Washington, D.C.: Institute for International Economics.

Christensen, Jakob. 2004. Domestic Debt Markets in Sub-Salharan Africa. IMF Working Paper, No. 04/46. Washington, D.C.: IMF.

Dollar, David and Aarr Kray. 2002. Growth is Good for the Poor Joumal of Ecomomis Grouth 7 (3): 195-225.

Dornbusch, Rudi. 2000. Keys to Prosperity: Free Markets, Sound Money, and a Bit of Luck. Cambridge, Mass.: The MIT Press.

Easterly, William. 2001. 'The Elusive Quest for Grouth: Economists' Adventures and Misaduentures in the Tropics. Cambridge, Mass.: The MIT Press.

Fischer, Stanley. 2004. IMF Essays from a Time of Crisis: The Intemational Financial System, Stabilization, and Development. Cambridge, Mass.: The MIT Press.

Gautarn, Madhur. 2003. Debt Relief for the Pewrest: An OED Revitw of the HIPC Initiatize. Washington, D.C.: The World Bank.

Gilpin, Rohert. 2000. The Challenge of Global Capitalism: The World Economy and its Discontents. Princeton, NJ: Princeton University Press.

Greenhill, Romilly, Ann Petrifor, Henry Northover and Ashok Sinha. 2003. Did 
the G8 Drop the Debt. London: Jubilee Debt Campaign.

IMF. 2003. Debt Sustainability in Low-Income Countries - Towards a Forward-Looking Strategy. Policy Development and Review Department. Washington, D.C.: IMF, March.

IMF. 2003a. Hoavily-Indebted Poor Countries Initiacive: Fact Sheet. Washington, D.C.: IMF.

IMF-IDA. 2003. linhanced HIPC Initiative - Creditor Participation Issues. Washington, D.C.: International Monctacy Fund and International Development Association, April 8.

IMF-IDA. 2004. Heavily Indebted Poor Countrics (HIPC) Initiative-Statistical Lpdate. Washington, D.C.: International Monetary Fund and International Development Association, March 31.

Sachs, Jeffrey. 1986. Managing the LDC Debt Crisis. Brookings Papers on Economic Actinity Issue 2: 397-431.

Stern, Nicholas. 2002. A Sirategy for Development. Washington, D.C.: The World Bank. United Nations Development Program (UNDP). 2003. Human Development Repurt 2003. New York: Oxford University Press.

World Bank. 2002. Glibalization, Growth and Poventy: Building An Inclusive World Economy. New York: Oxford University Press.

World Bank. 2002a. Global Development Finance 2002. Washington, D.C.: The Workd Bank.

World Bank. 2003. Global Ecomomic Prospects and the Developing Countries. Washington, D.C.: The World Bank.

World Bank. 2003a. Sustainable Development in a Dyramic World: Transforming Institutions, Gronth and Quality of Life. New York: Oxford University Press.

World Bank. 2001. Glabal Monitoring Report 2004: Policies and Actions for Achieving the Millennium Development Gouls (MDGis) and Kelated Outcomer. Background Paper, April 16, Washington, D.C.: The World Bank.

World Bank. 2004a. Partnerships in Development: Pmgress in the Fight Against Poverty. Washington, D.C.: The World Bank.

World Bank. 2004b. Global Development Finance 2004. Washington, D.C.: The World Bank.

\section{ENDNO'IES}

1 Throughout much of the $19 \% 0$; "Drup the Debt", a Btitish non-governmental organization ( $\mathrm{V}(\mathrm{OO})$, arlvucated the complece canceliation of all debt owed by poor countries. Drop the Debr was later merged with "Jubilee 2000 UK" to form the new organization called Jubilee Research. They first began carmpaigning for an independent framework for rcsolving international detor rrises in 1995 . Thus, from sich small beginning Jubilee Research has rapidly geown to become an international campaign for Third World debt-relief.

2 Somereign defitult is the failute of an obligor ro moce a principal or interest payment in a timely manner.

${ }^{3}$ Both authors argue that excessive debt burdens causes investors to hold back because they fear that their profits will $b x$ taxced to help service the debt, or that the debtor councry may resort to devaluation (and inflationary policies) as a way cope with the unpaid debt. Moreover, a debt overhang discoutages the 
debtor country from making necessary, but painful macmeconomic adjustments because of their concern that the fruits from reform will go for debt-servicing, while they bear most of the socioeconomic and political fidlout.

${ }^{1}$ In 1989 U.S. Treasury Secretary Nicholas Brady introduced a plan that took his rame under which the principal and some of the interest woukt be guaranteed with U.S. 'l'reasury bonds in cxchange for a write-down of the amounes outstarding. The Brady Plan debt reduccion, coupled with strengthening economies among the so-called "Brady 15" countries, helped a number of distressed middle-income debtors to return to financial stability. Most [xorr coututrics did not benefir from the Brady Plan, however, as mest of their debt was to the Paris Club creditor countries and multilateral lenders.

"Concessional l'reatment or concessionality can occur either theough a cancellation of part of the claims, or through a rescheduling of the claims over a long perioxl of time with an interest rate that is lower than the appropriate market rate. When a debt treatment sesults in a reduction of the net present value of the claims reschectuled, ir includes concessiosiality. Debe swaps include operations such as delo for nature, debt for aid, debe for equity swaps or other local currency debt swaps. These swaps often invulve the sale of the debt by the creditor government to an investor who in turn sells the debe to che debtor government in return for shares in a local company or for local currency to be used in projecrs in the country. IDA is the largest single sunrce of concessional aid to poor countries. Concessional financing is provided at substantially below market rare - with no incerest charge and repayments strerched over $35-40$ years, including a 10 year grace period. IDA levies a $\frac{3}{3}$ of $1 \%$ service charge on the disbursed balance co cover administrative costs.

- The Net Present Value (NPV) of debt is a measure that takes into account the degree of concessionality. It is defined as the sum of all future debt-service obligarions (interest and principal) on existing debt, discounted at the appropriate market race. Whenever the intcrest rate on a loan is lower than the market rate, the resulting NPV of debt is smaller than its face value.

Thac is, the IIIPC, for the firse timc, broughr all creditors - bilatcral, multilateral, and commercial lenders - within the same coordinated framework. It is important to note that the debt owed by a councry can be broken down into a rumber of different types: by debtor (which may be a sovereign government, a public company or a private debror), by creditor (which may be a multilateral crediror, a government., a private creditor). Over time, the share of private debt (debt owed by private debrors) and the shate of private claims (debt owed to private creditors) have increased, reflecting the increased role of the private sector in both industrialized and developing countries.

n During the debt-crisis, creditor governments formed a committec to agree on the needed debt relief. In consultation with the IMF they agreed that all creditors offered icrms at. least as favorable as those agreed by the committee. Hosted by the French Treasury, this committee became known as the "Paris Club." Patis Club crediturs agree to provide additional debe reduction under the HIPC Initiative as part of the overall effort to enable the councry to cxit from unsustainable debt. Consistent with current practice. councties receiving assistance from the Paris Club are required to scek treatment on debt owed to other bilateral and commercial creditors on terms at lease comparable to those agreed with the Paris Club.

9) When a debtur country first meets with Paris Club creditors, the "cut-off date" is defined and is not changed in subsequent Paris C.lul rreatments, and credits geauted after this cut-off date are not subject co future rescheduling. Thus, the cut-off date helps restore access to credit for debtor countries facing paymert difficulties.

${ }^{10}$ At the decision point, the Fxecutive Boards of the IMF and World Bank formally decide on a counery's cligibility, and the international community commits to provide sufficient assistance by the completion point for the country to achieve debt sustainaliality calculated at the socision point.

Any definition of sustainable debr embodies a value judgment of what is, and what is not, sustainable. The IIIPC. Initiative now defines a ratio of net presetic valuc of debt (NPV) to expurts in excess of 150 percent as unsustainabie.

${ }^{2}$ Poverty Raduction Strategy Papers (PRSPs) are prepared by governments in low-income countries through a participatory process involving domestic stakeholdters as well as external developonent partners, including the IMF and the World Bark. A PRSP describes the macroeconomic, structural and sncial policies and progranns that a county will pursuc over several years to promote broar-based growth and reduce poverty, as well as external financing needs and the associated sources of financing. Given the time which it may take countries to prepare a fully participaton PRSP, cuntries may submit only an interim PRSP (I-PRSP). ${ }^{13}$ To reach the complection point, countries must have satisfactorily finished the reforms they agreed to when they entered the formal HIPC Initiative process. The international community conmits to provide sufficient assistance by the completion point for the country to achicve debt sustainability. Thus, at the completion the country receives the bulk st its assistance under the HIPC Initiative, without any further policy conditions. However, under the enhanced HIPC Initiative, che siming of the completion point is linked $t o$ the implementation of pre-agreed key structural reforms (i.c., floating completion point).

${ }^{14}$ Most, but not all, creditors provide interim debt service relief between Decision Point and Completion Poinr. However, cven after countries have passed Decision Point, the provision af interim relicf is not guaranteed. 
:S Topping-up: in a subsequent debt reduction, graning more debt reducrion on debt the Paris Club previously reduced to provide even furcher debt relief (e.g., when increasing the caticellation level from 33.33 percent of Toronto terms to 67 percent of Naples terms).

"6 Through the International Development Association (IDA), the World Bank provides grants to the poorest countries. While it began as the part of the Bank that provided financial assistance to rhe wordd's pootest countries at zero interest, it is now providing oursight grant assistance to low-income countries. However, the predominant method of delivering relief on $1 \mathrm{D} A$ debt is through the forgiveness of a portion of IDA dubt service as it comes duc. IDA will forgive a minimum of 50 percent of the annual debt service due on existing IDA debt. IDA will to the extent possible deliver its full share of debt relief to the country within 20 yeas after the decision point.

${ }^{7}$ With regard to implications for overall debt reduction, the World Bank estimates suggests that after HIPC and traditional debt relief, including ODA cancellation, the net-present value of public debt in the threc-dozen countries likely to be cut by rao-thirds. For details see (IMF-IDA 2004, 11; and (http:ifwww.worldbank.org/ hipcifag/fag.html).

1A Jubilce Research believes that the very definition of 'sustainabilicy' is flawed. It argues that the Workd Bank offers no justification for the arbitrary level of sustainability set by the HIPC initiacive, as 150 percent of exports. Jubilee Research points out that initially the World Bank stated that there was "absolurely t10 intalyrical justification' for the rectuction of the level of sustainability from 200-250 percent to 150 percen when they reformed the initiative. Latet, the World Bank claimed that the extra debt relief was a 'cushion effect' in case the country's export earnings fell after it had received debe relief. In fact, the World Bank itself admits that the definition of debt sustainability is quite nartow as it does not deal with issues of domestic debt which are important for fiscal sustaimability. Nor does it measurc the actequacy of public resources to adkdress priority devclopmenr programs after debe scrvice has been made (Greenhill, Pettifor, Northover and Sinha 2003).

19 While Jubilec Research's propossals sound intuirively appealing, there are problems wit the. For example, the need for debe relief and grants would require a country-by-country judgoment of whar constitutes a satisfactory policy goal. This would not only be very diffeult in practice, it would porentially lcaed to vast differences in the definition of debt suscainability actoss countries raising obvions issnes of fairness. Also, since the proposals ane designed to put onus on the donor community to provide low-income countries with substantind ucc trassfers while simultarkerusly liniting sheir debt-strvice burden, making such a framework operational would requice shat donor countries be prepared to allocate a potentially unlimited amount of debt relict and grants to eligible countrics. Of course, this is not in the cards.

${ }^{20}$ Arrears ace debe due and noc paid as of a given date. Arrears may be late payments as well as debt due a long time before. The late incerest rate that accrues on arrears usually includes the original interest rate of the credits, plus a petralsy.

${ }^{21} \mathrm{Ot}^{-}$course, there is a danger in this. If countries like Iraq decide to become candidates for debt cancellation, it would put tremendous pressure on the HIPC Initiative.

${ }^{22}$ A recent IMF-IDA $(2003,4)$ report notes that "some creditors, mostly commetcial, have launched litigation proceedings against HIPC debtors to recover their outstanding claims. The actions reflect the fact that the HIPC Initiarive cloes not altet the legal rights and obligations lectween HIPC and their external credicors. Accordingly, until the HIPC debiors and their creditors reach bilateral legal agreements in line with the HIPC lnitiative, creditors are legally coritied to use available legal mechanisms to colorce their rredit claims against HIPCS. In some instances, prior to their decision points HIPCs have paid commercial creditors in fulf (and fotgone debt relief) either because of the litigation or the threat of it, a desire to awoid disrnyting a commercial relationship, or the fear of losing producrive assets in cascs where commercial debe was secured by collateral $\cdots$. So far, the number of such lawsuits and the amounts involved have been relacively smail, but such proceedings can be burdensome to che debturs comerned, and can in some cases complicare financial and reserve management in these countries." 